\title{
Anmeldelse:
}

\section{Monopoltilsynet svigter på Idéernes Markedsplads}

\section{Peter Wivel}

Amerikansk forsker laver faktatjek på det marked, hvor tonedannende meningsmagere angiver retningen for USA's udenrigspolitik - og dermed også for vores velfærd og sikkerhed. Akademiske intellektuelle viger pladsen for velbetalte 'tanke-ledere' med gribende enkle løsningsforslag. Kan det gå?

Daniel Drezner: The Ideas Industry. How Pessimists, Partisans, and Plutocrats are Transforming the Marketplace of Ideas. Oxford University Presse, 360 sider.

\section{1997 sendte Clayton Christensen, en} amerikansk økonom, en i bogstaveligste forstand epokegørende bog på markedet. The Innovator's Dilemma: When New Technologies Cause Great Firms to Fail lød dens alarmerende titel. Den ny teknologi, Christensen mente at have identificeret, betjente sig af 'disruptive innovation' - altså en omvæltning, der vender op og ned på gængse forestillinger om markedsbehov. Dens flydende struktur gør det umuligt at forudsige, hvilket marked den baner vejen for - og hvilket den lægger i grus, advarede Christensen.

Udgivelsen faldt tidsmæssigt sammen

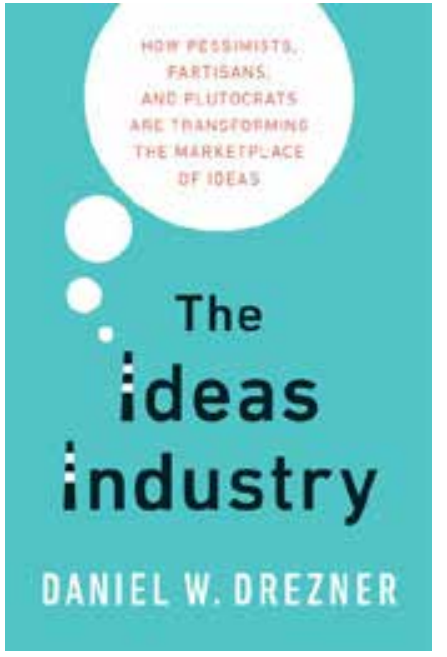

med det kvantespring i amerikansk produktivitet, som it-industrien bidrog til op mod årtusindskiftet. På den anden side ventede vigtige sociale medier som Facebook (2004), Twitter (2006), WhatsApp (2009) og Instagram (2010).

Christensens idé sprængte hurtigt sine akademiske rammer og invaderede sammen med de ny medier politikkens verden. Samfundets forandring lå i 'disruptive politics'. 
Er akademiske bidrag til den offentlige debat dermed definitivt ude af billedet som back up for beslutningstagere? Må 'public intellectuals' vige pladsen for 'thought leaders', altså debattører, hvis idéer og tanker gør dem til samfundsdebattens ledere, skønt deres synspunkter mest af alt er reklamesøjler for deres egne, bedragerisk enkle synspunkter? Har fake views besejret real views på 'Ideernes markedsplads'?

Det spørgsmål nager Daniel W. Drezner, professor i international politik ved Fletcher School of Law and Diplomacy ved Tufts University, Massachusetts, og prominent blogger ved avisen Washington Post. Han besvarer det i sin seneste bog The Ideas Industry, How Pessimists, Partisans, and Plutocrats are Transforming the Marketplace of Ideas, der har fået glimrende anmeldelser i seriøse amerikanske medier.

\section{Disruptive politics}

Christensens managementteorier ligger i dag i ruiner, efter at andre forskere har påvist en række graverende faktuelle og metodiske fejl i hans skrift, konstaterer Drezner. Men de stortrives på en politisk markedsplads, som de ikke var skabt til at betjene, da demokratisk politik må og skal tage andre hensyn end dem, der styres af markedskræfterne.

En række faktorer bidrog til den succes, Christensens teori om 'disruptive innovation' høstede. Den ene store idé, der mener at kunne forklare alt, er i dag en sikker vinder. Desuden lancerede Christensen scenevant et trusselsbillede, og intet får folk til at løbe hidsigere i samme retning på såvel børs - som på debatmarkederne som pessimisme. Teorien markedsførte sig selv - og det var også meningen fra Christensens side.
Endelig tiltalte hypotesen USA's superrige entreprenører og igangsættere. De var overbeviste om, at deres succes ene og alene skyldtes deres personlige kreativitet og risikovillighed, mens de fortrængte, at samfundets infrastruktur, love og allerede eksisterende markeder gav deres hånd med. De var 'disrupters', og den tanke investerede de gerne millioner $i$.

Christensens teori oplevede, i sin politiske version og naturligvis utilsigtet, sin storhedstid under præsident George W. Bush, hvis chefideologer fortolkede angrebet på USA den 11. september $2001 \mathrm{ad}$ samme baner. Supermagten USA forsikrede sine fjender, at den ville væbne sig mod ethvert forsøg på 'disruptive politics' og asymmetrisk krig med forebyggende slag, 'preemptive' strikes.

I dag troner Donald Trump, Bushs seneste efterfølger, i Det Hvide Hus. Aldrig har 'disruptive politics' fejret større triumfer.

Men hvordan er det kommet så vidt? Det giver Drezner sit bud på. Han er selv en 'public intellectual', der er vant til at udtrykke sig let og forståeligt for et stort publikum. Med udgangspunkt i sit fagområde, amerikansk udenrigspolitik, beskriver han den langsomme forskydning fra faglig kompetent information og vurdering til sensationelle og ensidige partsindlæg. De sidste når ud til det store publikum og dermed også til beslutningstagerne i Washington, hvor Vestens sikkerhed og økonomiske velfærd i vid udstrækning afgøres.

Drezner er ikke alarmist. Han har tillid til, at det bedste argument vinder i sidste ende. Men denne sidste ende ligger desværre ofte på den forkerte side af katastrofale beslutninger som $\mathrm{fx}$ præsident Bushs Irak-invasion i 2003 eller sammenbruddet på det amerikanske subprime-marked fra 2007 til 2010. Præsident Bush, hans 
administration og det meste af det politiske establisment overhørte kvalificerede advarsler og lyttede i stedet til toneangivende ideologer i deres egne rækker eller i medierne.

Hvis det var et problem i 00'erne, er det ikke blevet mindre i dag. 'Disruptive politics' er kommet for at blive.

\section{Viden og fordomme}

Drezners bog er ikke en teoretisk afhandling. Som så mange andre udgivelser på det amerikanske marked for politisk litteratur tager den en ny tendens op, søger at identificere dens årsager og vurdere dens betydning, illustreret med centrale eksempler og paradigmer.

For udenrigspolitisk interesserede er bogen en fremragende indføring i den verden, fagets analytikere befolker. Teksten er en letlæst, levende og ekstrem faktanær overvejelse over vores efterhånden begrænsede muligheder for at fortolke den verdenspolitiske situation og dens trusler på en relevant måde.

Rollefordelingen mellem en 'public intellectual 'og en 'thought leader' er groft sagt den samme som mellem viden og fordomme, mellem skepsis og præk, mellem tvivl og overtalelse. Den ene er kritiker, mens den anden tilbyder løsninger. Alt sammen illustreret med et billede, hentet fra den antikke græske digter Arkhilokhos, der ordret siger, at "ræven ved mange ting, men pindsvinet én stor". Disse ord blev et paradigme i den britiske filosof Isiah Berlins berømte essay The Hedgehog and The Fox (1953).

På det direkte plan er årsagen til, at tanke-lederen har forskubbet den intellektuelle debattør, at finde i tre parallelle udviklinger.

Den første er det autoritetstab, som offentlige myndigheder, universiteter, politi- kere og medier har lidt. En del af skylden bærer disse institutioner selv. De afskærmer sig og ringeagter akademikere, der deler deres viden med offentligheden. Dertil kommer, at akademikere ikke er ret meget bedre til at spå om fremtiden end professionelle 'thought leaders'. Det ligger for så vidt i sagens natur, da verden reagerer på politiske tildragelser, der som regel alle skyldes god eller dårlig rådgivning.

Autoritetstabet forstærkes af, at prisen på en adgangsbillet til meningsmarkedet er faldet til nul i den ekstremt kritiske, hvis ikke direkte hadefulde offentlighed, der er opstået i og forstærkes af algoritmer på sociale medier, som Drezner i øvrigt ikke frakender værdi som samfundskritisk røst. Dertil kommer, at det ultrakonservative USA målbevidst går efter en minimalstat. Ved gode ord og betaling skaber plutokratiet, som Drezner kalder de superrige, en offentlighed, hvor minimalstat og 'USA først' er den ledende tanke.

Den anden årsag ser Drezner i polariseringen af amerikansk politik. USA's akademikere er langt mere liberale end offentligheden i øvrigt. Det gælder især inden for udenrigspolitik og i mindre grad inden for økonomi. Det betyder ikke, at de to fløje, højre og venstre, ikke begge kan udføre et professionelt stykke arbejde. Men hældningen til venstre gør det nemt for konservative tanke-ledere at ignorere akademisk kritik på meningsmarkedet. Liberale meningsdannere kan på deres side, ikke uden grund, kritisere konservative for at være forudindtagede, hvis de ikke $i$ et og alt er betalt for deres meninger. Ingen af parterne lytter til hinanden.

\section{Markedspladsen for ideer}

Den tredje, sidste og måske afgørende faktor er den tiltagende og dramati- 
ske ulighed i det amerikanske samfund. De superrige, plutokratiet, saboterer institutioner, der hidtil har sikret ikke bare magtbalancen i USA, men også landets kolossale forspring, når det gælder højere uddannelse, forskning og produktion af viden. Plutokratiet har skabt sin egen vidensproduktion og deres eget marked for idéer. Hvor der er marked, er der også profit, og hvis viden har værdi, må der også være nogen, der fastsætter den.

Drezner viser, at tænketanke, som tidligere tjente den amerikanske stats udenrigstjeneste eller forsvaret, i dag erstattes af mere eller mindre akademiske institutioner, der varetager private interesser, det være sig tænketanke, analyseinstitutter, tech-rugekasser eller konsulentfirmaer. De arbejder som regel direkte for sponsorer eller på kontrakter, hvis de ikke varetager bestemte politiske interesser sådan som $\mathrm{fx}$ Heritage Foundation eller Cato Institute (hvor danske Flemming Rose, en typisk 'thought leader', er senior fellow). De har direkte forbindelse til beslutningstagerne, det har universiteter ikke.

Markedspladsen for idéer kårer vindere og marginaliserer tabere. I første division lå engang intellektuelle superstars som John Maynard Keynes, George Orwell, Bertrand Russel, Joseph Schumpeter, Wal- ter Lippmann, George Kennan, John Kenneth Galbraith, Henry Kissinger og fx Noam Chomsky. Ingen af dem indgik i den markedsøkonomi, der nu dominerer scenen.

Længere nede har vi i dag en stribe 'public intellectuals', der er endt som 'thought leaders' på idéernes markedsplads. I dag anføres holdet af trioen Thomas Freedmann, Niall Ferguson og Fareed Zakaria. De følger efter veteraner som Samuel Huntington, Francis Fukuyama, Paul Krugmann, Joseph Stiglitz og fx Thomas Piketty.

For Drezner er det afgørende ikke højre eller venstre, ikke valget mellem det forbeholdne eller det uforbeholdne. Markeds$ø$ konomi hviler på, at bankerotte produkter forsvinder fra markedet. Virker det princip også på idéernes markedsplads?

Nej. Drezners bog viser, at tærsklen for fallit på denne markedsplads er faretruende høj. Akademikere oplæres i kritik, for kun kritisk forskning kan i sidste ende afgøre, hvad idéer kan forklare, og hvad de ikke kan forklare. På idéernes markedsplads gælder andre principper. Populære idéer, der sælger, kan selvfølgelig til enhver tid kritiseres. Men udryddet bliver de ikke af den grund. Ofte tværtimod.

000 